\title{
Observations on Drivers and Dynamics of Environmental Policy Change: Insights from 150 Years of Forest Management in British Columbia
}

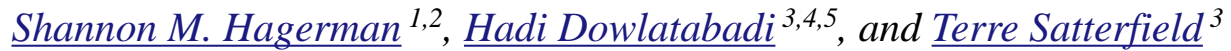

\begin{abstract}
Human and ecological elements of resource management systems co-adapt over time. In this paper, we examine the drivers of change in forest management policy in British Columbia since 1850 . We asked: How has a set of system attributes changed over time, and what drivers contributed to change when it occurred? We simultaneously examined a set of three propositions relating to drivers and dynamics of policy change. We find that factors contributing to the level of impacts, like technology, changed substantially over time and had dramatic impacts. In partial contrast, the institutions used to exercise control (patterns of agency and governance) remained the same until relatively recently. Other system attributes remained unchanged (e.g., the concept of ecosystems as stable entities that humans can manage and control). Substantive, decision-relevant uncertainties characterized all periods of management but did not act as a barrier to the adoption of new regimes at any time. Against this backdrop of constancy in some attributes, and change in others, a few exogenous drivers (e.g., technology, war, markets, legal decisions, ideas, and climate) triggered episodic reexamination of guidelines for resource management. The implications of these findings for future policy change in this system are discussed.
\end{abstract}

Key Words: British Columbia; change; drivers; forest management; global change; historical analysis; science and policy; social-ecological system; uncertainty

\section{INTRODUCTION}

Biophysical and human (social-cultural) elements of landscapes co-adapt and change over time. By elements, we mean a constituent part or component. These changes are the result of social, political, and ecological processes that interact across scales (e. g., Gunderson et al. 1995, Gunderson and Holling 2002, Wynn 2004). Although humans and the biophysical environment have always interacted (Crumley 1994), the complexity and scale of the interrelationships has increased in recent centuries and decades (Turner et al. 1990, Goudie 2000). Land-use change, genetically modified organisms, geopolitical events, transmission of disease, distal accumulation of toxic compounds, the consumption patterns and impacts of 6.6 billion people, and climate change are cases in point.

The impacts of climate change, in particular, present substantial challenges for resource managers and policy makers. Changing temperature and precipitation regimes (International Panel on Climate Change 2007) are projected to impact natural disturbance dynamics (Dale et al. 2001), interspecific interactions (Araújo and Luoto 2007) primary production (Nemani et al. 2003), and microbial activity (Rinnan et al. 2007). Indeed, the impacts of climate change have already been linked with changes in species distributions (Root et al. 2003, Parmesan 2006, Lenoir et al. 2008).

These projected and observed changes contrast with management policies that are based on equilibrium assumptions of ecosystem behavior and that tend to support a "command-and-control" approach to managing natural resources (Holling and Meffe 1996). A command-and-control approach assumes that ecosystems are well-bounded entities, governed by linear cause-and-effect relationships and are predictable given the right information. Examples include the management of forests for a predictable and steady timber supply and the management of biodiversity for species persistence 
within static protected areas. Alternatives to command-and-control policies have been advocated for decades; however, in many cases, policies based on assumptions of ecological stability continue to persist in practice.

The incompatibility between non-linear landscape dynamics, and control-type policies, in combination with the apparent persistence of these policies, prompts the following question: What factors might eventually contribute to policy change that does incorporate an understanding of dynamic systems, limited control, and limited predictive capacities? We use the case of forest management in British Columbia (BC) to examine the history and drivers of past changes in this system. In doing so, we propose some likely key factors over time.

The literature relating to biophysical and socialcultural aspects of BC forests is rich, although relatively discrete with respect to its integration across disciplinary boundaries. On the one hand, natural scientists have contributed to an understanding of the biophysical patterns and processes operating in BC forests. A selection of this work includes ecosystem classification (Krajina 1965, Pojar et al. 1987); examination of the role of natural disturbance such as fire (Lertzman et al. 2002) and insects (Taylor and Caroll 2004); plantdisease interactions (Baleshta et al. 2005); belowground dynamics (Simard et al. 1997) and net ecosystem productivity (Humphreys et al. 2005).

On the other hand, environmental historians, political scientists, and sociologists have examined the human dimensions acting in BC forests. Some have focused on interactions among technology, mechanization, and labor (Rajala 1998, 2006, Marchak 1983); others have sought to explain changes in forest policy at specific times by focusing on various combinations of market pressures, interests, institutions, and ideas (Hoberg 1996, Lertzman et al. 1996, Howlett 2001). Still others have focused on the political, scientific, and ideological aspects of conservation and environmental movements in BC at various times (Wilson 1998, Wynn 2004), and in Canada more broadly (Gillis and Roach 1986, Loo 2006).

The aim of this paper is to merge insights from these disciplinary perspectives to provide an integrated empirical analysis of the biophysical and social elements of change in the BC forest system over time. The purpose of using a historical approach is to understand the drivers and dynamics of policy change in this system over time in order to extract insights into potential future iterations of change. By drivers, we mean key factors and forces (potentially from either or both biophysical and social domains) for which there is empirical evidence to indicate a measurable contribution to a set of observed phenomena. By dynamics, we mean patterns of policy change over time (e.g., gradual and incremental, sudden and episodic, or some combination). In doing so, we are interested in the possibility that there may be commonly observed patterns and key variables contributing to change in this system in particular, and the possibility of cautiously drawing lessons for understanding change in linked social-ecological systems more broadly.

We use the regional provincial boundary (BC) to delineate the system and our analysis. This is the scale of the key forestry and conservation legislation governing management and use in the province. This boundary further serves our purpose of drawing coarse-scale insights into the drivers and dynamics of change at a regional scale. Importantly, rules for resource use in the provincial system also include federal legislation, but analysis at that larger scale does not fit with the analytical objectives of this paper. However, we do examine drivers external to this regional boundary where implicated. In our analysis, forces acting external to this boundary are referred to as exogenous, those within are referred to as endogenous.

\section{Conceptual Foundations}

Before proceeding, we outline the key concepts that shape our analysis. Broadly, our approach adopts the perspective that social-ecological systems (SES) (Berkes and Folke 1998) are co-produced systems that display multi-scalar, historically contingent, non-linear change dynamics (Crumley 1994, Gunderson and Holling 2002, Berkes et al. 2003, Walker et al. 2004, Reynolds et al. 2007). This view derives jointly from Holling's seminal work on multiple stable states and non-equilibrium behavior of ecological systems (Holling 1973) and related insights on non-linearity, path dependence, and multiple potential outcomes in complex adaptive systems (e.g., Levin 1998). More specifically, this work is situated and interpreted in the context of three literatures: (1) resilience theory; (2) theories of policy change; and (3) social theories of science and policy. 


\section{Resilience theory}

Resilience theory is an integrative theory of change that examines processes and drivers of change in complex adaptive managed systems (Gunderson and Holling 2002). It is integrative because it reaches beyond "partial perspectives" by drawing from and synthesizing insights from the fields of ecology, economics, and institutional analysis (Holling et al. 2002:8). The adaptive cycle, within which change dynamics may pass through four phases (growth, conservation, release, and reorganization), is a central metaphor used by resilience scholars to understand change (e.g., Allison and Hobbs 2004).

\section{Theories of policy change}

From the policy sciences, we draw from scholarship related to the question of what causes policy change and why. Our interests lie in change over time. For this reason, we sought insight from research that has examined this question in historical contexts (e.g., Baumgartner and Jones 1991, Kingdon 1995, Sabatier and Jenkins-Smith 1993, Hajer 1995, Pierson 2004, Repetto 2006, Sabatier 2007). These authors and others have used and devised various frameworks and approaches to explain (a) drivers and (b) dynamics of policy change over time.

\section{Drivers of change}

Some scholars argue that shared "belief systems" (value priorities and perceptions of what matters), and policy learning through technical debates are key variables in policy change (and resistance to change) (Sabatier and Jenkins-Smith1993, Sabatier 2007). With some similarities, Hajer (1995:22), argues that policy making is an "interpretive activity" shaped by particular discursive understandings of a given problem. As with Sabatier and JenkinsSmith (1993), Hajer uses the concept of coalitions (discourse coalitions in the latter case) as important sources of policy change. However, Hajer (1995: 71) highlights the "unstable value positions" of individuals that change over time in response to new "story lines."

From a slightly different perspective, Kingdon (1995) argues that specific factors increase the chances of new proposals surviving the "selection process" and contributing to change: new proposals need to have gone through a gestation period of "softening up;" they must be ready and feasible; and similar to the perspectives outlined above, they must reflect the values of key actors.

\section{Dynamics of change}

Other scholars highlight that understanding policy change at a given point in time requires understanding the history of preceding events because historical events set path-dependent processes that shape outcomes removed in time (e. g., Pierson 2004). Path dependency has been defined as "dynamic processes involving positive feedback, which generate multiple possible outcomes depending on the particular sequence in which events unfold" (Pierson 2004:20). Key features of path dependency include self-reinforcement (positive feedbacks) and trajectories that become entrenched over time. Without attention to past dynamics, we may fail to recognize key variables explaining a given phenomenon (Pierson 2004).

Still others argue that policy change proceeds "incrementally" (Lindblom 1959) over time. And that incremental change occurs for intrinsic (that is the way the world works) and strategic reasons (cf. Kingdon 1995). Or with more nuance, that incrementalism applies to some aspects of policy change, such as the generation of new alternatives, but not to the larger process of agenda setting (Kingdon 1995). Lastly, some scholars have adopted Stephen Gould's punctuated equilibrium metaphor from evolutionary biology, arguing that change tends to occur in punctuated spurts of substantive and infrequent change that follow prolonged periods of relative stasis (e.g., Baumgartner and Jones 1991, Kingdon 1995, Howlett and Ramesh 2003, Repetto 2006). Reflecting the social variables that are commonly studied within the policy sciences, key contributing factors of policy change include the role of social movements, ideas, technology, actors, institutions, market forces, learning, and scientific information.

Combined, research from resilience theory and theories of policy change have converged on the shared observations that a relatively small set of key variables underpins complex phenomena of change, that external events are often critical determinants of policy change, and that historical events and slowly unfolding processes contribute to phenomena removed in time. Moreover, the adaptive cycle predicts similar change dynamics to a punctuated equilibrium model (and carries with it the benefit of integrating ecological variables). For instance, 
Gunderson and Holling (2002) describe the dynamics of adaptive cycles as follows: "cycles of slow accumulation of natural and cultural capitalin an ecosystem, an institution, or a society-are interspersed with rapid phases of reorganization where, for transient moments, novelty can emerge to become subsequently entrained."

\section{Social Theories of Science}

Lastly, because of the central importance often attributed to the role of science in policy debates, we draw insights from social theories of science to help us understand the roles and non-roles of science (e.g., Jasanoff 2004, Oreskes 2004, Pielke 2004). Decades of research in this field have shown that the domains of science and society cannot be neatly separated in practice. Evidence from these researchers and others does not support assumptions of a linear model of objective scientific information passed untainted by human values to inform policy decisions. Rather there are subjective values at play during all phases of knowledge production and application in policy debates (Jasanoff 2004). Furthermore, historical research has shown that "scientific proof is rarely what is at stake in a contested environmental....issue." And that in environmental policy, there is "no need to wait for proof, no need to demand it and no basis to expect it" (Oreskes 2004).

\section{Questions and Propositions}

Having now established the aim of this paper, and our conceptual foundations, the analysis that follows explores the following questions $(Q$.$) and$ propositions $(P$.$) , relating to the determinants and$ dynamics of policy change in a specific SES. As derived from the insights outlined above, we are particularly interested in understanding what changed and why, the role of scientific information and uncertainty, and more broadly, observed patterns of policy change through time. The historical approach and analysis that follows enables us to explore these propositions empirically. In the concluding section, we discuss which aspects of these propositions our evidence supports, and instances where anomalies and further research questions are indicated.

Q1. How has a selected set of system attributes changed over time? What drivers were key contributors of change when it occurred? From what scale and what domain did these factors originate?
$P 1$. The degree of influence of different drivers varies with origin (exogenous vs. endogenous to the system), domain (e.g., social, ecological), and over time.

Q2. In what ways did the presence of scientific uncertainties shape policy responses over time?

$P 2$. The presence of decision-relevant uncertainties is not in-and-of-itself a barrier to the adoption of new policy proposals.

Q3. Do the observed patterns of policy change in this system align with common models of change?

P3. Policy change in this system has proceeded according to a punctuated equilibrium model.

\section{Approach and Data}

We use an integrated assessment-inspired framework (IA) to organize this analysis and to maintain a focus on historical processes and policy implications. Across its various formations, IA approaches share the following features: interdisciplinarity (placing the problem in broader context-both in time and beyond disciplinary borders); identification of uncertainties (to identify what we can and cannot know within a decision context); which together provide insights for decision making (Rotmans and van Asselt 2000). Thus, key groups of variables for IA include (a) attributes of governance (agency, institutional arrangements, and decision-making processes); (b) inputs to decision making (stated objectives of key actors, scientific uncertainties, technology, markets, and biophysical drivers), and (c) outputs of decision making over time (e.g., area harvested, area planted, area set aside as protected). We collected historical data on these variables dating from 1850 to present (Table 1). This grouping of variables is used for analytical purposes, but governance, inputs, and outputs are, of course, coproduced across scales and domains in practice.

Data collection included a thorough reading of provincial and federal Royal Commissions and legislation; ministry annual reports; Hansard reports (verbatim records of legislative debates); agency publications; conference proceedings; newspaper articles; industry association publications, and Statistics Canada and BC Stats reports. Secondary sources included scholarly analyses of forest policy in BC. To assess the impacts of scientific uncertainties on decision making, we selected two 
Table 1. Table of variables examined in the SES of BC forest management from 1850-present. The variables are grouped by categories that include attributes of governance, inputs to decision making, and outputs of decision making.

\begin{tabular}{lll}
\hline \hline Attributes of Governance & Inputs to Decision Making & Outputs of Decision Making \\
\hline Agency & Stated synthesis objectives & Area and volume harvested \\
Institutional arrangements & Scientific uncertainties & Area reforested \\
Decision-making process & Technology & Area of parks and protected areas \\
& Markets & \\
\hline
\end{tabular}

core scientific issues in forest management during this period: forest inventory and forest regeneration. Qualitative accounts of certainty and uncertainty were collected from the archival materials listed above as well as from inventory reports, and peerreviewed literature.

This paper proceeds from here in three parts. We begin with a description of the region of focus. This is followed by a historical profile in which a consistent set of variables is examined through time (Table 1). Lastly, we discuss the historical data in relation to the questions and propositions introduced above and draw some broader implications for understanding policy change in linked SES.

\section{AREA OF FOCUS}

\section{Bio-Physiographic-Climatic Components}

British Columbia spans 11 degrees of latitude and 25 degrees longitude, and occupies a total area of land and freshwater of 95.2 million hectares (Meidinger and Pojar 1991). The region is influenced by four sub-continental climatic regimes (Demarchi 1995) and includes all nine of the major soil groups found in Canada. Various combinations of physiography, climate, and soils are used as a basis for a range of ecosystem classification schemes. As one example, the Biogeoclimatic Ecological Classification delineates 14 regional zones that currently include desert, grassland, wetland, a range of forest types, and alpine tundra (Fig. 1).
Over $60 \%$ of the provincial area (approximately 59 million ha) is classified as forest, which ranges in type from coastal temperate forests to interior-dry forests to the northern boreal forest. A number of natural disturbance processes have influenced currently observed biotic patterns. These vary by ecosystem in frequency, intensity, and scale and include fire, pathogens, insect activities, wind events, drought, and flooding (Wong et al. 2004, Daniels and Gray 2006). In addition, human activities including logging, mining, agriculture, settlements, road development, the introduction of non-native species, fire suppression, and controlled burns have impacted in the past and continue to impact observed biotic patterns.

\section{Current Forest Ownership and Governance}

The provincial government owns approximately $93 \%$ (55.2 million ha) of the total forest area in this region. Federal and private ownership comprise $1 \%$ and $3 \%$, respectively. Access to publicly owned forest land in BC (Crown land) is defined by property rights that grant forest licensees the rights to harvest timber on a given parcel of land for a renewable period of 15 or 25 years. In return, forest licensees pay a fee at the time of harvest to the provincial government. This contractual agreement and all forest activities in BC are currently governed by the legislation contained within the Forest and Range Practices Act.

Currently, approximately $13.5 \%$ of the total provincial area (13 million ha) is set aside within 
Fig. 1. Biogeoclimatic zones of British Columbia. Used with permission of the Research Branch, Forest Science Program, British Columbia Ministry of Forests and Range.

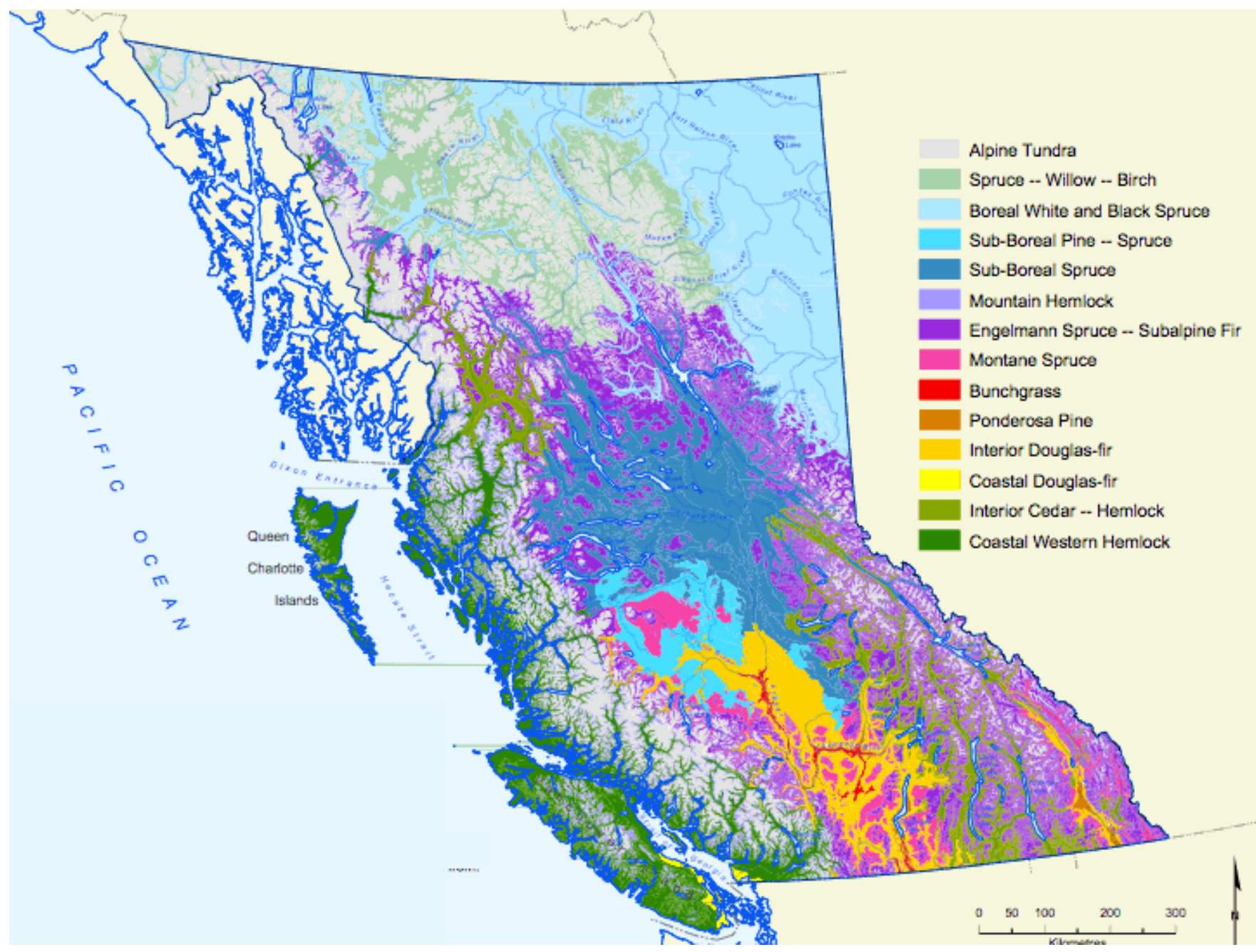

protected areas, ecological reserves, biodiversity areas, conservancies, or recreation areas. Statistics compiled in 2002 indicate that forested lands comprise approximately 5.75 million ha of the area under protection (Niemann 2006). Protected areas are currently administered by the Ministry of Environment and, among other regulations, are governed by the Protected Areas Act, the Park Act, and the Ecological Reserves Act. Protected areas and forests are managed under separate administrations, but as the history below indicates, this has not always been the case. Moreover, because land-use designations are currently considered within a sub-regional-level decisionmaking process, the history and future of forest and biodiversity management in $\mathrm{BC}$ is necessarily examined together.

\section{Current Socioeconomic Attributes}

Since official records, the population of $\mathrm{BC}$ has grown from a reported 32000 in 1867 to 4.5 million residents in 2009. Approximately 50\% of the population resides in the mostly urbanized southwest corner of the province (Niemann 2006). 
The forest sector currently accounts for approximately $7 \%$ of provincial employment and comprises $15 \%$ of economic activity (indirect and induced activities). Lumber, natural gas, and coal are the province's three main exports (Niemann 2006). Other key provincial industry sectors currently include agriculture, construction, mining, and tourism.

\section{A HISTORY OF CHANGE AND STASIS IN BC'S FORESTS}

The timeline of this history of BC's industrial managed forests is presented in five periods. The first division is marked by the inaugural forest act in 1912. The following two divisions are marked by Royal Commissions in 1943 and 1976. The last division is marked by changes in governance that occurred in 1992. Data for each of the variables are reported within in each of the five periods, lending a consistent structure to the presentation of data in this section.

\section{Industrial Beginnings (1843-1912)}

At the time of European settlement in BC (1843), forests were perceived by colonists to possess no particular value over other landscape types. Timber was cut to clear land, construct settlement buildings, and support agricultural progress. Timbered lands were equal in cost to other landscape types and as noted by the federal Commission on Conservation: "...the standing timber was considered of no great value" (Whitford and Craig 1918). Perceptions began to change in the mid 1850s. The end of the fur trade, the discovery of gold on the Fraser River, timber-supply disruptions as a consequence of the American Civil War, and the biophysical qualities of Douglas-fir (Pseudotsuga menziesii) all combined to increased demand for coastal $\mathrm{BC}$ timber. By the 1860s, BC timber was exported to water-based markets throughout the Pacific Rim including South America, China, Japan, Australia, and New Zealand (Whitford and Craig 1918, Gillis and Roach 1986).

Technological changes further transformed the value of timber and the scale of operations. The construction of the railways throughout the $1880 \mathrm{~s}$ was particularly influential. Construction created local demand, opened eastward rail-based markets, and - with rail lines built directly into timber stands -increased access to timber that had previously been unavailable beyond about $5 \mathrm{~km}$ from a waterway (Whitford and Craig 1918). Other influential technological changes included the mechanization of forest operations by steampowered cable logging (mid 1870s), which served the function that oxen had previously of transporting $\log$ s to water or skid road (Fig. 2).

Private interests accessed Crown timber primarily by a land ordinance in which licenses were issued to cut timber for a non-transferable term of 1 year. There was no regulation as to how much timber could be cut, or in what manner. This particular configuration of social and ecological elements resulted in the following outcomes: the number of sawmills in BC increased from 25 in 1888 to 224 by 1911 (Whitford and Craig 1918, Marchak 1983) and the total volume of timber cut on provincial lands increased from an estimated $317551 \mathrm{MBF}$ $(\mathrm{MBF}=1000$ board feet) in 1903 to $1060000 \mathrm{MBF}$ in 1911-1912 (Whitford and Craig 1918). During this period, the population of BC increased 12-fold from an estimated 32000 (1867) to 393000 (1911) (BC Stats).

Despite this activity, a perpetual forest industry was not yet envisioned. Agricultural settlement remained the priority use for "timbered agricultural lands" (Province of BC Department of Lands 1913). At the same time, many conservationists (those who promoted the economic development of timbered lands) called for more information about the distribution of trees across the landscape. In 1902, the Commission of Conservation was established to compile a province-by-province inventory of timber resources. Given the area, topography, and access throughout $\mathrm{BC}$ at the time, it would not be an exaggeration to say that the scale of this task with respect to estimating standing timber was enormous. In the end, the authors noted that published estimates were essentially "confined to guesswork" (Whitford and Craig 1918).

Meanwhile, BC's first provincial park, Strathcona, was established (1911) to satisfy a different set of objectives. The objectives relating to parks during this period were more narrowly defined than they are today. Then, the mandate of parks was to "set apart as a public park and pleasure ground for the benefit and advantage, and enjoyment of the people of British Columbia" (Province of BC 1911). This 
Fig. 2. Logging practices in the early 1900s and currently: (A) skid logging on Denman Island, BC, ca. 1904. Image A-07086 courtesy of Royal BC Museum, BC Archives; (B) cedar logging on the west coast. Source: BC Ministry of Forests and Range. [online] URL: http://www.for.gov.bc.ca/dsi/Scaling. htm.

A)

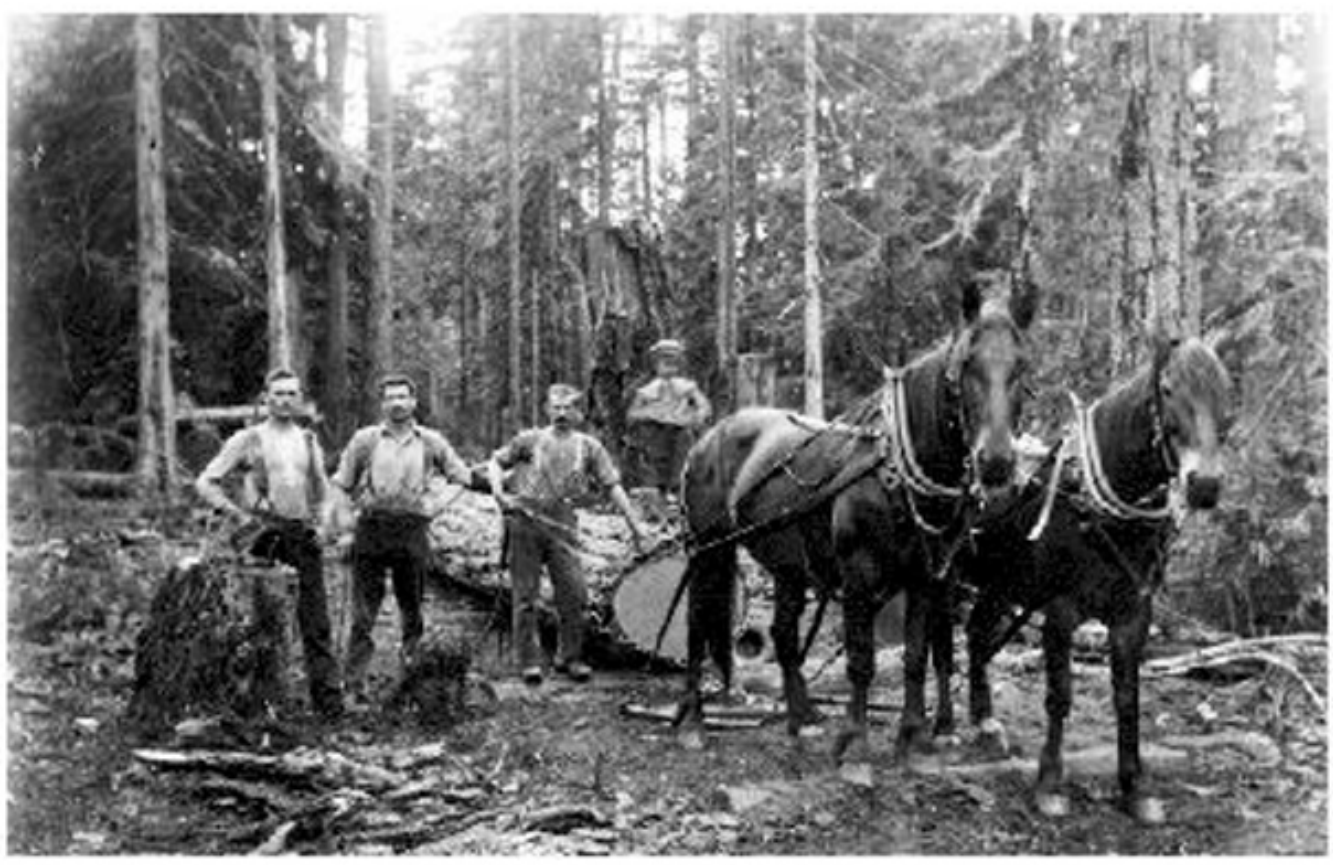

B)

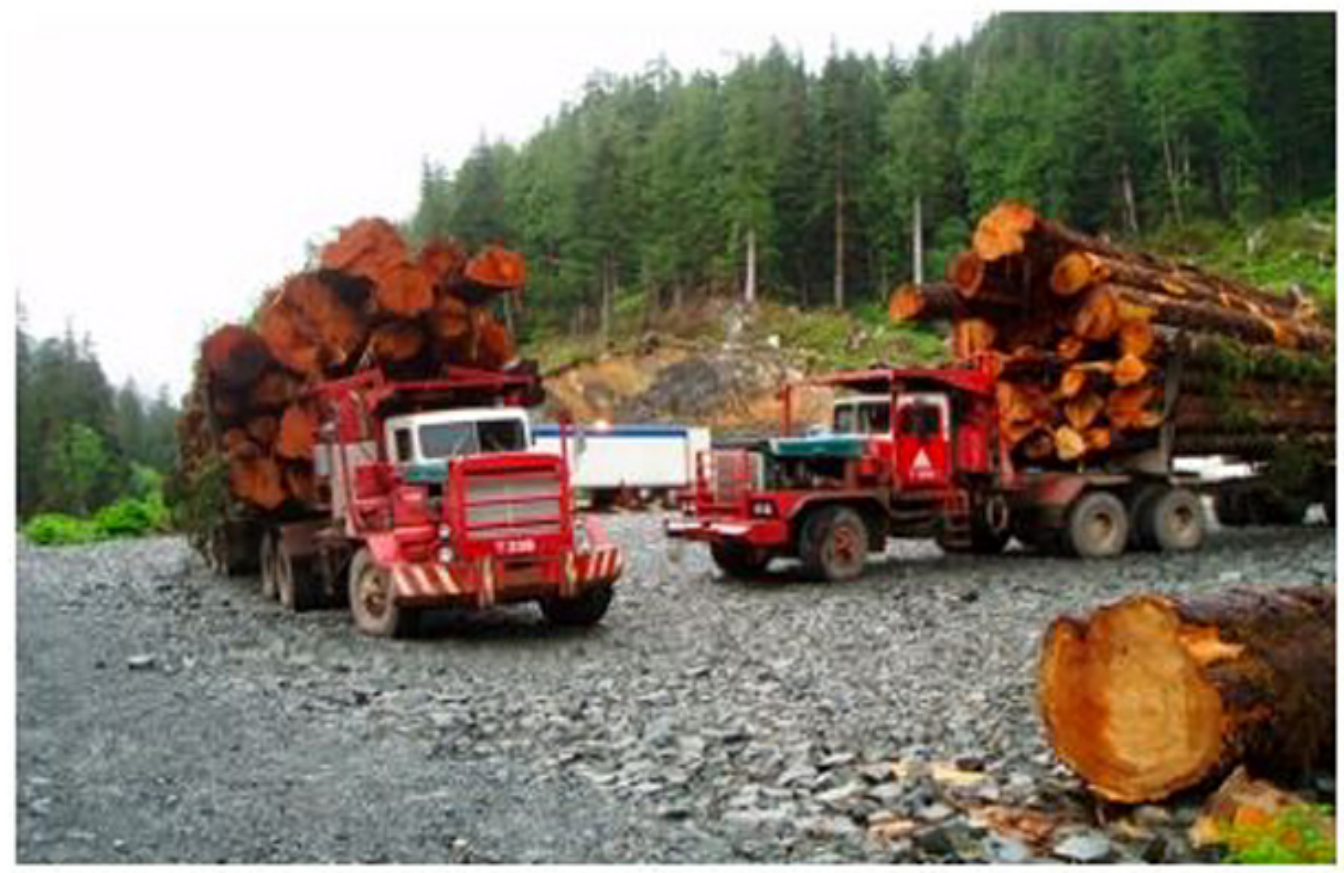


mirrored the language of earlier national initiatives. For example the Dominion of Forest Reserves and Park Act (1908) similarly states that national parks serve as "...pleasure grounds for the benefit, advantage and enjoyment of the people of Canada."

By the end of this period, land acquisition by private interests driven by international market demand, new technologies, and a growing population triggered concern among industrial-focused conservationists over access to land and a lack of ownership agreements. This prompted the first Provincial Royal Commission on BC forests and led to the formalization of the industry.

\section{Formalization (1912-1943)}

The Fulton Commission (1909-1910) led to the first Forest Act (1912) and the establishment of the provincial Forest Branch. The Act introduced various mechanisms of leasing Crown land to private companies under the condition that a portion of the revenues would return to the province (see Marchak et al. 1999). This contractual agreement clearly defined the actors in the BC forest industry: the provincial government owned the land and collected rents, and industry operators paid rent to harvest timber on it. This system of property rights satisfied the stated objectives of the province, which were to increase provincial revenues through: "timber utilization" and to "increase the annual cut" (Province of BC Department of Lands 1913). The primary objectives of industry operators were to acquire more land, increase the efficiency of operations (e.g., through increased mechanization), and turn a profit. Toward the end of this period, labor organizations became a third actor.

Technological (e.g., gasoline- and diesel-powered trucks and the refinement of the power saw), and market drivers (increased international demand) continued to shape the industry's activities and outcomes on the landscape. Biophysical drivers, including the mountain pine beetle (Dendroctonus ponderosae), the spruce budworm (Choristoneura occidentalis), and fire also impacted the landscape. The combined impacts of the mountain pine beetle and the western pine beetle (Dendroctonus brevicornis) were reported to have "destroyed most of the yellow pine occurring in pure stands in the Province" (Mulholland 1937). At the same time, these disturbances and others had little impact on the trajectory of harvesting outcomes at the regional scale. It was not uncommon for instance, for the introductory section of the Forest Branch annual report to begin by outlining a litany of disturbances such as "heavy snowfall" that delayed operations, "unprecedented floods" (Province of BC Department of Lands 1939), or a "disastrous fire season" (Province of BC Department of Lands 1938), which was then followed by a statement such as "in spite of these, the year closed with a record log scale" (Province of BC Department of Lands 1939).

Indeed, the volume of timber harvested during this period maintained an upward trend with periodic fluctuations correlated with geo-political (e.g., World War I, the 1929 stock-market crash, and the Depression) more than biophysical drivers (Fig. 3). By the end of this period (1943), the harvested timber volume had nearly tripled (14.64 million $\left.\mathrm{m}^{3}\right)$ from levels at the beginning of this period. As in the preceding period, logging methods and the amount cut were unregulated, and there were no formal incentives for operators to ensure forest regeneration.

Amidst this accelerating logging activity, the Forest Branch considered the perpetuation of the forest industry insofar as it asserted that a second crop of trees on logged coastal lands was "best obtained by clear-cutting followed by slash burning" (Province of BC Department of Lands 1913), or in the Interior, by natural regeneration. Thus, in addition to inventory estimates, knowledge of seedling regeneration dynamics was also required for management. Both contained substantial uncertainties.

It is very important, if we are to build up a technique for proper forest management in the widely different forest conditions of the Province, that investigations of systematic character and conducted with scientific accuracy form an important part of the work of the service. At the present time we are severely handicapped by a lack of reliable information ... (Province of $\mathrm{BC}$ Department of Lands 1921).

From the inception of the industry, there were doubts that commercially desirable species would regenerate naturally. Yet, reports of the Forest Branch continued to include claims that natural regeneration would suffice and that the alternative (artificial regeneration by planting nursery-grown seedlings) was "impracticable" (Province of BC 
Fig. 3. Summary of forest management regimes, key events, and harvesting levels in BC over time.

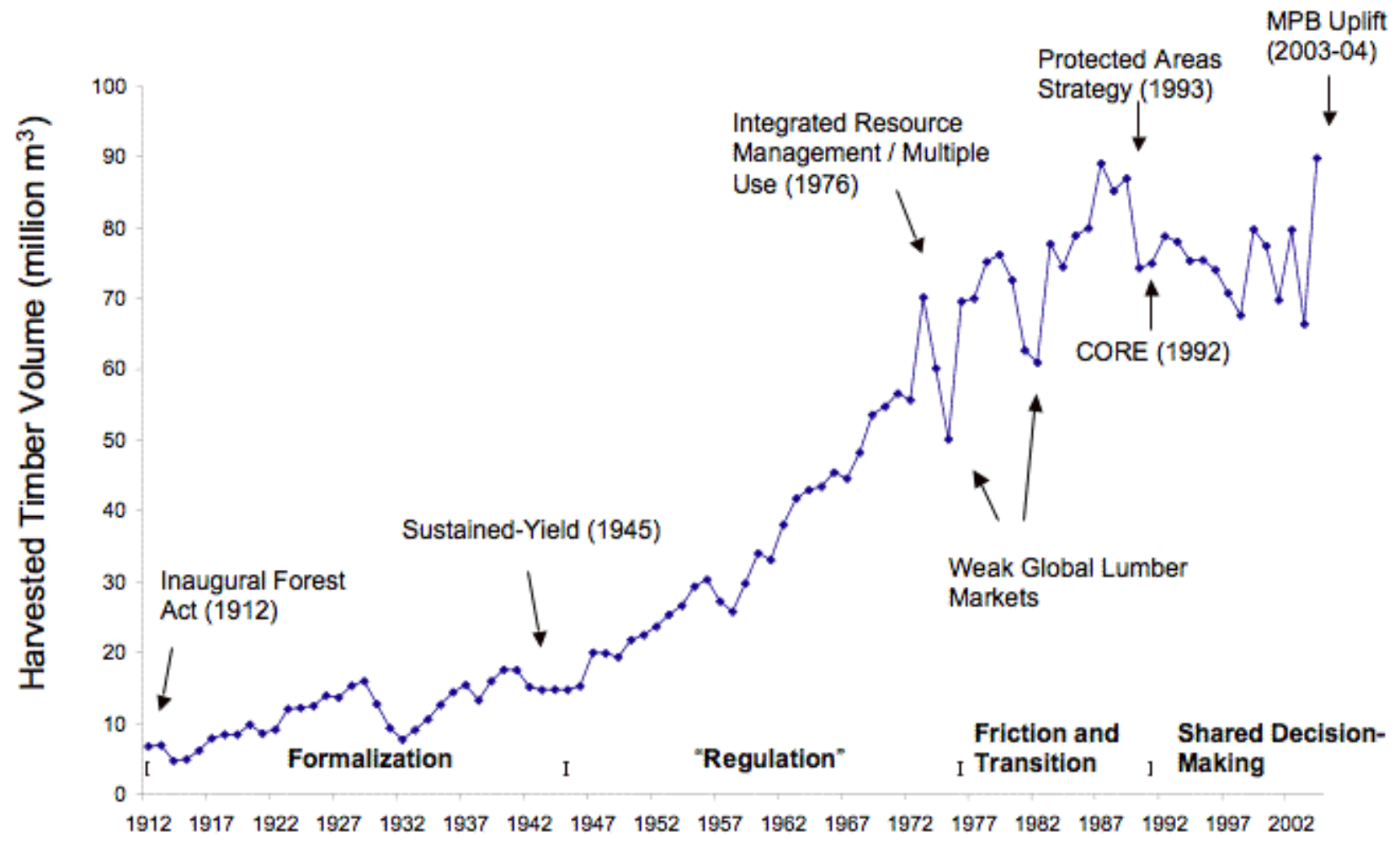

Year

Department of Lands 1914). Meanwhile, evidence was mounting in direct contradiction. The 1926 annual report included reference to the observation that hardwoods, including poplar and birch, (not desired conifers) predominated in some logged stands in the central interior of the province (Province of BC Department of Lands 1926). Ten years later, the Forest Branch stated that: "the regeneration of logged lands on Vancouver Island and the adjacent Mainland constitutes the most urgent silvicultural problem facing the Province..." (Province of BC Department of Lands 1936).

During this period, amendments to the Forest Act in 1939 made the administration of new parks the responsibility of the Forest Service. The amendment also introduced the first classification scheme (inviolate Class A parks to Class C recreation sites) and gave Cabinet the authority to "extend, reduce or cancel" parks. Consistent with the previous period, the stated objectives of parks were "pleasure and recreation." By 1945, 52 provincial parks comprised a combined area of approximately 4.4 million ha (Sloan 1945) (Fig. 4).

The second provincial inventory was published toward the end of this period. It reiterated previous concerns about "unsatisfactory reforestation" while also introducing concern over "the rapid expansion of industries" (Mulholland 1937). It was now generally acknowledged that existing forest practices combined with increasing demand would soon outstrip the accessible (coastal) forest supply. A second Royal Commission was established "to 
Fig. 4. Total area of parks and protected areas over time (m ha) (sources: Ministry of Forests Annual Reports; Department of Recreation and Conservation State of the Environment 2007).

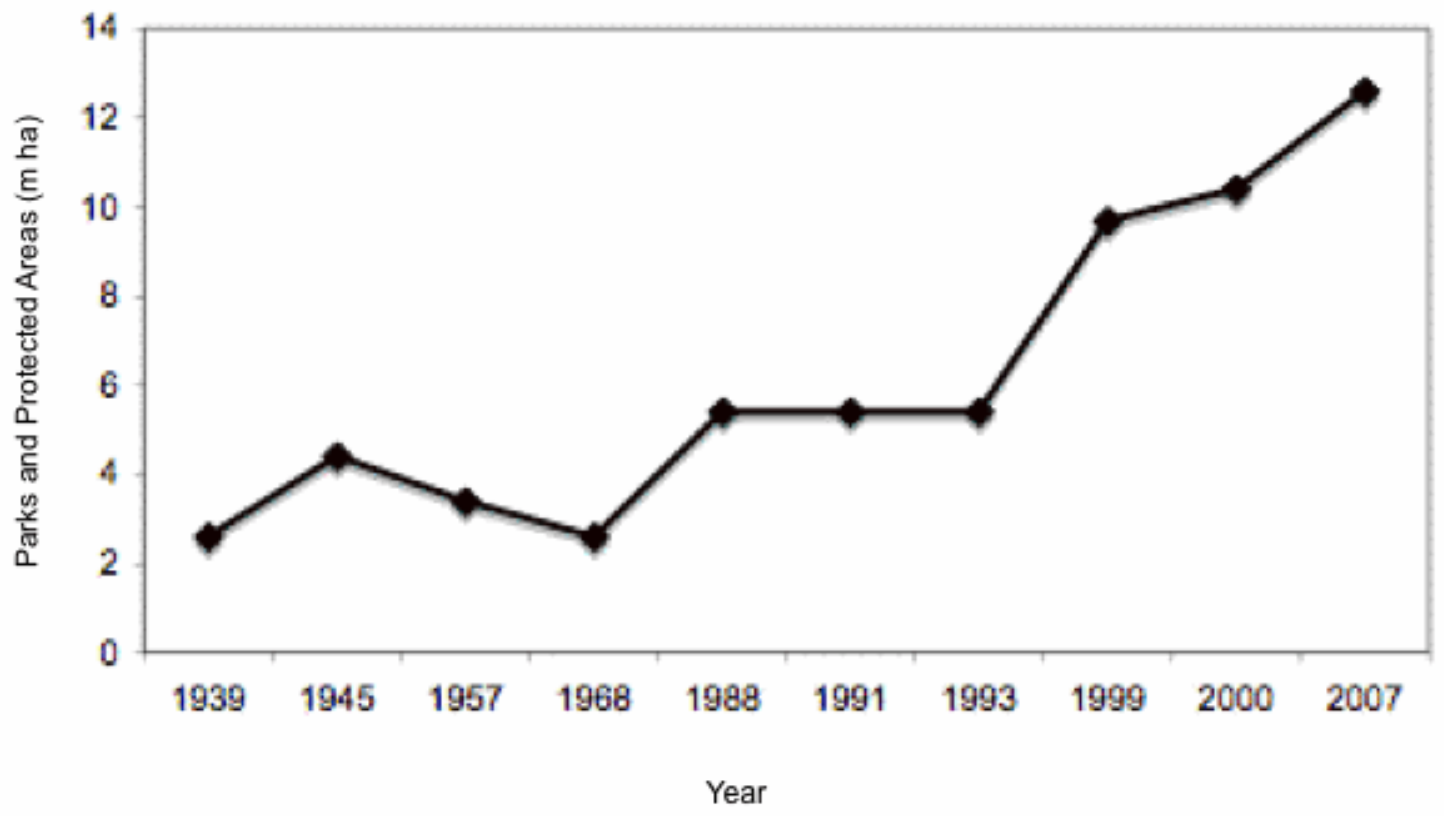

inquire into all phases of the forest industry of the Province" (Sloan 1945) and, specifically, to formalize a means within which regulation and "the continuous production may be assured from all our forest land."

\section{"Regulation" (1943-1974)}

The 1945 Royal Commission introduced the concept of sustained yield (SY) as a policy solution to the objective of "continuous production." Sustained yield was defined as "a perpetual yield of wood of commercially usable quality from regional areas in yearly or periodic quantities of equal or increasing volume" (Sloan 1945). Sustained yield was designed to satisfy the objectives of the two major actors: it was promoted as a means to achieve the "stability of regional communities" and the economic growth of the province by "...ensuring a perpetual supply of raw material for forest industries with consequent stability of industrial communities and assurance of permanent pay-rolls" (Sloan 1945). This was to be achieved by the "liquidation and conversion" of "static virgin" stands, replacement with the desired "normal forest," and regulation and management including forest regeneration thereafter.

The concept of sustained yield and proposals to regulate the cut were introduced in the face of explicitly acknowledged uncertainties about the very conditions required for its implementation (e. g., the volume of mature timber in a given area, rates of growth of naturally regenerating trees). As stated in the Commissioner's Report:

The regulation of the cut-especially during the harvesting of the second rotation crop-depends on a thorough knowledge of forest increment on sites of various yield quality. That information will not be 
obtainable except through experimentation and research over a considerable period of time (Sloan 1945).

The Commissioner further concluded that to achieve regulated forest management, "the presently denuded productive land areas not restocking must be replanted..." (Sloan 1945). Consistent with the previous period, this position was opposed by powerful actors including the Chief Forester and Minister of Forests at the time. As a consequence, SY carried no contractual obligation for industry operators to regenerate logged stands. This legal responsibility at the expense of licensees would not come until 40 years later. It is, therefore, not surprising that from 1945 to 1955 the amount of area classified as "not sufficiently restocking" (NSR) more than doubled on the coast from an estimated 372000 ha to 697000 ha (Sloan 1957). The total (coastal and interior forests) estimated NSR area in 1955 was 4.8 million ha (Sloan 1957).

During this period, planting programs expanded beyond experimental studies to include production landscapes. But to put these efforts into perspective, the percentage of area planted relative to area logged remained skewed by a fledgling planting program that was outpaced by the rapidly increasing cut. In 1943, at the beginning of this period, approximately $10 \%$ of the area of harvested Crown land was replanted (4607 ha planted vs. 43698 ha harvested). Over a decade later in 1955, this percentage decreased to $5 \%$ as the area harvested nearly doubled whereas the area planted remained the same (4379 ha planted; 86466 ha harvested). By 1965, the area planted had increased to approximately $11 \%$ of the total harvested area (15 172 ha planted; 129645 ha harvested).

The demand for timber products increased steadily following World War II as a result of both domestic and international markets. This occurred in tandem with increased mechanization and the specialization of logging trucks. At this time, the wood supply in the interior of the province was relatively unutilized for timber production (comprising $17 \%$ of the total provincial cut in 1943). This meant that SY posed little challenge to the trajectory of timber cut in the province as a whole, as operations expanded into the interior (reaching $50 \%$ of the total provincial cut by 1974). In fact, the annual volume of timber harvested during this period increased by almost $400 \%$. Rising from 14.64 million $\mathrm{m}^{3}$ in 1943 to
70.14 million $\mathrm{m}^{3}$ in 1973. In 1973 alone, the amount of timber scaled increased by $24.2 \%$ over 1972 $\left(55.60\right.$ million $\left.\mathrm{m}^{3}\right)$ levels.

In 1957, after two decades within the Forest Service, the administration of parks was moved to a separate department. The objectives for parks continued to be "the pleasure and recreation of the public" (Province of BC Department of Recreation and Conservation 1957) for economic benefit.

In harmony with this recreational plan, the park system...in time must blanket the Province. In this way all sections of $B C$ will be used and enjoyed by our citizens. A major consideration in implementing the recreational plan is economics (Province of $\mathrm{BC}$ Department of Recreation and Conservation 1957).

Less than a decade later, ecological attributes were added to the valued objectives of parks. In 1964, Nature Conservancy Areas (NCA) were introduced to give "absolute protection to outstanding areas of scenic, faunal and floral environment" (Province of BC Department of Recreation and Conservation 1964). Ecological objectives were further articulated in the Park Act (1967), where park categories now included those for which the "main purpose of its designation is the preservation of its particular atmosphere, environment or ecology."

These additions coincided with growing interagency tension over land use and growing public discontent with forest practices. In 1969, the Forest Service sought to distance itself from the past SY era by proclaiming "the start of a new era for the Forest Service with direct involvement with programmes involving multiple-use of Crown wooded land" (Province of BC Department of Lands, Forests and Water Resources 1969). In fact, managing forests for "multiple uses" was not a new idea within the Forest Service: it can be traced back to agency documents as early as the 1930s.

It is becoming increasingly apparent that we must value our forests not only as a source of our supplies of timber, but also for their many other uses-as food and shelter for our game and fur-bearing animals, as regulators of the water-flow of the streams in which we fish, and as attractions for the tourist and other recreationists who delight 
in the great outdoors. Our forest areas must be developed and protected from fire in the interests of these "multiple uses" (Province of BC Department of Lands 1936).

Similarly, the history of criticism toward forest management in BC dates back to the beginning of the industry (Brownstein 1996). However, it was not until 1971 that the Forest Service reported that "steadily mounting public interest and concern over forest-land uses resulted in the firming up of 'balanced use' policies..." (Province of BC Department of Lands, Forests and Water Resources 1971). Three years later this was explained as follows:

... the new resource planning system calls for input from all land-use agencies involved before any Crown land is committed to logging or any other form of industrial operation. The system considers fish, wildlife, watersheds, recreation, soils, stream protection and a host of other factors related to the environment (Province of $\mathrm{BC}$ Department of Lands, Forests and Water Resources 1974).

Balanced, or "integrated forest management" replaced the language of SY. Although acknowledging that these were early days for this "new" forest management, discussions relating to multiple use in the 1972 annual report were confined to the introductory remarks and the public relations section: "with continuing public concern over use of forest land, the Service's public relations programme placed heavy emphasis on the balanced use concept" (Province of BC Department of Lands, Forests and Water Resources 1972). No mention was made of actual policies for implementing multiple use. By 1975, public concern over forest practices and industry demands for tenure reform prompted a fourth Royal Commission.

\section{Friction and Transition (1976-1991)}

This was a transitional period for forest management in BC. It began with the report of the Royal Commission in 1976 and amendments to the Forest Act (1979) that posed no substantial challenge to existing attributes of governance or logging practices. It ended with multiple public protests, mass arrests at logging sites, international media coverage of logging practices, new actors in the decision-making process, and a "dramatic shift in values" (BC Forest Resources Commission 1991).

As foreshadowed by events at the end of the last period, the amended Forest Act (1979) included the directive for the Ministry of Forests to plan for multiple uses. This came in response to emerging concerns about the protection of ecological values. It also staked out the Ministry's position that the best approach to managing timbered landscapes was for multiple uses (not single uses such as protected areas). Attributes of governance, including the key actors in the system, remained as they had in past, and the stated objectives of the Ministry of Forests continued to be to "maximum productivity."

Meanwhile, ecological concerns had crystallized as a central issue in international agencies (e.g., the UN World Commission on Environment and Development (1987) and the UN Convention on Biological Diversity (1992)), academic domains (e. g., the emerging field of conservation biology and associated organizations); and in the media (e.g., articles on BC logging practices, such as the 1 December 1991 "Canadian Chainsaw Massacre" piece in the UK's The Observer). One of the outcomes of this collective focus was the call for more protected areas: “... the total expanse of protected areas needs to be at least tripled if it is to constitute a representative sample of Earth's ecosystems" (WCED 1987). This statement has been interpreted as the $12 \%$ target by 2000 , and we will see that it directly influenced protected areas policy in $\mathrm{BC}$.

Proposals for protected areas were at odds with a century of BC forest practices that had singularly prioritized timber production. They were also at odds with the concept of multiple use. Ministry of Forests officials and industry leaders responded by railing against suggestions for "single-use" land designations like protected areas. Dave Parker (then Minister) stated, "I have a personal problem with single purpose use of the land base... Single purpose use in many cases makes very thin soup" (Vancouver Sun, 11 June 1988). At a symposium on BC parks, the president and CEO of the main industry association (Council of Forest Industries) at the time, stated his concern that "accessible, high-value forests" would be "removed permanently and given over to single uses...." He proposed instead that "integrated resource management such as selective or salvage logging in some parkland could actually enhance recreational and aesthetic values" (Lanskail 1985). 
Although the Ministry claimed a "greater emphasis on planning for the full spectrum of resource uses with involvement of other resource management agencies" (Province of BC Ministry of Forests and Lands 1987), the harvesting outcomes for this period indicate that this planning - to the extent that it existed-had no measurable impact where timber extraction was concerned. In fact, the conceptual transition from the sustained yield to integrated resource management coincided with successive record volumes in the amount of timber harvested (69.9 million $\mathrm{m}^{3}$ in $1977,75.2$ million $\mathrm{m}^{3}$ in 1978 , and 76.2 million $\mathrm{m}^{3}$ in 1979). Production decreased in the early 1980s (reaching a low of 60.94 million $\mathrm{m}^{3}$ in 1982) due to the downturn in the global economy, reduced US demand, falling lumber prices, and labor strikes. But by the mid 1980s, harvesting volumes had rebounded, breaking records each year (79.9 million $\mathrm{m}^{3}$ in $1986 ; 89.05$ million $\mathrm{m}^{3}$ in 1987). Toward the end of this period, harvesting levels fluctuated between 86.9 million $\mathrm{m}^{3}$ in 1989 and 74.92 million $\mathrm{m}^{3}$ in 1991.

At the same time, the proportion of area replanted increased from approximately $25.6 \%$ in 1979 to $50.4 \%$ in 1980 . However, due to increasing cuts and the backlog of NSR lands, the area of harvested NSR land remained high, in the range of 3.9 million ha (Pearse 1976). Finally, in 1986 (after more than a half a century of evidence indicating the failed regeneration of many harvested stands), the provincial and federal governments announced a commitment to replant NSR lands. Furthermore, amendments to the Forest Act in 1987 made reforestation to free-growing status a contractual obligation of operators (at their own expense) on Crown land.

While the Ministry was promoting "multiple use," it was also reassuring the public that it would be consulted on land-use decisions: "Special efforts will be made to ensure that the public has input in resource-use decision-making..." (Province of BC Ministry of Forests and Lands 1987). However, the increasing cut prompted many observers to note that this amounted to little more than tokenism (Drushka 1999). The phrase "talk and log" (see Wilson (1998) for his book of the same name), represented the view that government and industry were proceeding with decision making as they had in the past. Logging moratorium studies and community-level efforts to limit logging in wilderness areas date back to the early 1970s. However, it was not until the mid 1980s that individuals, environmental groups, and First Nations organized an increasing number of blockades across the province in opposition to logging operations. The 1993 blockade in Clayoquot Sound, for example, is reported to have resulted in the largest mass arrest in Canadian history.

Amidst this growing public discontent, the Parks Branch was elevated to its own Ministry (Province of BC Ministry of Parks 1988), with an "increased emphasis on protection and management of $\mathrm{BC}$ natural heritage." This period culminated in a provincial election where the would-be new government campaigned on the promise of forest practices reform and environmental protection in keeping with WCED recommendations.

\section{Shared Decision Making (1992-Present)}

By 1992, changing public values, increasing international and provincial scrutiny of $\mathrm{BC}$ forest practices, commitments to international conventions, and a newly elected provincial government combined to influence change in the policy configuration of the system. Within a relatively short period, attributes of governance, including the actors in the system and the decision-making process, changed for the first time in the industrial history of the system. This occurred in combination with the implementation of a suite of new initiatives and legislation.

One of the first of these initiatives was a new multistakeholder, consensus-based decision-making process (the Commission on Resources and the Environment 1992). One year later, a similar (subregional) process was initiated (Land Resource Management Plans (LRMP)). The Commission on Resources and the Environment was disbanded after 4 years, but the LRMP process continues as the decision-making framework within which land-use decisions at the sub-regional scale are negotiated. In both these initiatives, environmental NGOs and First Nations joined the perennial actors in the system (industry and the provincial government). The two new groups gained agency in different ways: ENGOs through international markets campaigns, and First Nations through the Supreme Court of Canada. Other initiatives and policies occurred in rapid succession and included the Forest Sector Strategy Committee (1993), the Forest 
Renewal Act (1994), the Forest Practices Code (1995), the Timber Supply Review (1992-1993), the Biodiversity Strategy (1992), and the Protected Areas Strategy (PAS) (1993) to name a few.

In particular, the goal of the PAS was to double the area under protection (12\% by 2000). This has now been achieved (Fig. 4). Between 1991 and 2007 protected areas increased from approximately 5.3 to13 million ha. The objectives expressed in the PAS echoed previous legislation in that they included both recreation and ecological values. As for ecological considerations, ecosystems were defined as: "an integrated and stable association of living and nonliving resources...". (Province of BC (1993), emphasis added).

Recent planning processes have adopted a more dynamic conception of ecosystems, including links with human systems. For example, efforts toward ecosystem-based management (EBM) use the concept of ecological integrity (EI), defined as "the abundance and diversity of organisms at all levels, and the ecological patterns, processes and structural attributes responsible for the biological diversity and for ecosystem resilience" (Coast Information Team 2004). With a stated focus on ecological processes, efforts toward EI appear to contrast with the static definition of ecosystems as articulated in the PAS. At the same time, the objectives of protected areas within an EBM framework are to "protect representative samples of all native ecosystems and species...sustain viable populations of native species..." (Coast Information Team 2004). The assumptions of stability implicit in the latter statement (e.g., the focus on native ecosystems and species and assumptions of stable species ranges) arguably still reflects past approaches more than it indicates planning for dynamic system behavior that may likely include shifting species ranges as a consequence of climate and concurrent changes.

A clear example of a dynamic, non-linear ecological and social process is currently unfolding across millions of hectares of the interior of the province. As of 2009, the mountain pine beetle had infested an estimated 14.5 million ha of forest. Insects and disease are common disturbance agents in temperate forests (Dale et al. 2001), and the endemic mountain pine beetle has reached outbreak levels in this region in the past (Safranyik et al. 1974). However, the current outbreak is larger than previously recorded (Safranyik and Carroll 2006). Moreover, the ecosystems that will develop following this disturbance are unclear.

The beetle outbreak has provided justification for an increased cut in some areas explained as an "emergency measure for salvaging and recovering the greatest value possible from beetle attacked timber" (BC Ministry of Forests and Range 2008). In 2004, with the "beetle uplift" in place, total cuts were 89.8 million $\mathrm{m}^{3}$. This highpoint occurred after a period of decreasing cuts in the mid 1990s (78.01 million $\mathrm{m}^{3}$ in 1993, 67.6 million $\mathrm{m}^{3}$ in 1998). These reductions came on the heels of new structures of governance and legislation. However, market factors are strongly implicated in that temporary decline. Hoberg (1996) has argued that the "high prices and expanded markets for BC wood products" in the early 1990s created a situation that was conducive to regulation. In essence, it became politically feasible for the government to implement regulation and protected areas, and affordable for the industry to concede.

Consistent with the preceding periods, this period was characterized by the presence of scientific uncertainties relevant to the decisions being made. Some of the uncertainties persisted from earlier periods (e.g., inventory):

Accurate and up-to-date inventories of all forest values are critical to the success of any resource management policy. They form the basis for land use classification decisions and provide the raw materials used to determine the appropriate level of enhanced stewardship called for in the Vision Statement. Without this information, Land Use Planners and forest managers are severely hampered in making intelligent choices and recommendations. Sadly, the state of renewable forest resource inventories in this province is inconsistent at best, and woefully inadequate at worst (Commission on Resources and the Environment 1992).

Other uncertainties became increasingly relevant as new management objectives were introduced. For example, the focus on biodiversity and protected areas introduced uncertainties relating to the size, design, location, and management of protected areas. More recently, the impacts of climate change have introduced a barrage of uncertainties relating to future species distributions. These include 
uncertainties relating to biotic interactions (Pearson and Dawson 2003, Guisan and Thuillier 2005), dispersal (Pearson 2006), disturbance (Woodward and Beerling 1997), the potential for rapid evolutionary change (Gienapp et al. 2008), and interactions between the dynamics across scales.

Figure 3 summarizes the key social and ecological events in the history of forest management in this system.

\section{DISCUSSION}

\section{Attributes and Drivers of Change (What Changed and Why?)}

\section{System attributes and outputs}

The historical evidence shows that the outputs measured for this system changed substantially over time (Figs. 3 and 4). In partial contrast, attributes of governance remained static for most of the period examined, with changes occurring only in the last decade or so. Lastly, despite widespread recognition that ecosystems are dynamic, command-andcontrol-type resource management has remained in practice.

A central question of this analysis is: where change was detected, what were the contributing drivers of change $(Q 1)$ ? For harvesting outputs, the evidence indicates that exogenous drivers (war, technological change, international markets, and climate) overwhelmingly influenced the cut. Sometimes these drivers pushed the cut downward, but over time, the trend was upward (Fig. 3). Exogenous drivers, including ideas, were similarly influential in contributing to changes in the amount of area protected and changes in governance. This general observation of the importance of external drivers is supported by theories of adaptive change, which predict that change in managed SES often requires an external force to release "social and political gridlock" (Gunderson and Holling 2002). The importance of external triggers is further demonstrated in empirical studies where concepts from both resilience and the policy sciences have been applied (e.g., Light et al. 1995, Sabatier 1997, Abel et al. 2006, Repetto 2006).

Of the exogenous drivers noted above, the policy consequences, common origins, and labile quality of ideas are worth highlighting. By ideas, we mean collections of assumptions, evidence, experience, morality, and cultural norms that form conceptions of how the world works, or ought to work. Different terms are used in other literatures to describe a similar concept. In the risk and decision sciences, "ideas" as we see them are termed "mental models." In political ecology, ecological anthropology, and cultural geography, a more power-infused equivalent is "discourses." All make the point that, in interaction with other social and ecological factors, ideas have material policy consequences. They can prevent or catalyze change and they contribute to shaping the nature of change when it occurs. Ideas do so by implicating or justifying certain policy options and simultaneously obfuscating or discrediting others. For example, in this system, ideas of stable, pristine (non-human influenced) ecosystems have underpinned protectedareas policies that seek to maintain species in place over time and that historically have restricted human activities.

As to the origins of ideas that spur change, Light et al. (1995) observe that: "...new understanding usually emerges from the periphery, it often appears as hearsay to the prevailing myths and dogma." Thus, in the absence of external sources of ideas, prevailing values held by the status quo can act as powerful barriers to change. Here, we similarly find that ideas external to the system were catalyzing drivers of change. For example, although there had been decades of discontent about forest management among naturalists in BC (Brownstein 1996), measurable changes in policy outputs only came on the heels of international conventions, protests, and market campaigns.

Lastly on ideas, we know from environmental historians (e.g., Cronon 1996, Loo 2006) and economists (J. M. Buchanan, unpublished manuscript) that ideas and their expression in policy objectives that were suitable for the social, ecological, and technological context of one time period may be either ill suited, not desired, or untenable in a different time period and context. Buchanan invokes the concept of "relatively absolute absolutes" to describe the reality that the ideas, norms, and values that represent a given "constitution" of alternatives at a given time are stable in the short term, but prone to change in the long term (J. M. Buchanan, unpublished manuscript).

Using the concept of exogenous (and endogenous) as a class of driver requires distinction on at least three issues. The first concerns within-class 
variation. $P 1$ posits that the relative influence of exogenous drivers varies across domain (e.g., social, ecological) and over time. As for the first part of this proposition, our data indicate that "social"-exogenous drivers were particularly influential in this system (at the spatial scale defined) for most of the time profile examined. Technological, geo-political, economic, and cultural (ideas and social movements) factors consistently influenced the outputs in this system. The evidence suggests the need for further distinction still because these exogenous social drivers had different rates of change. New technologies, wars, and markets changed system outputs relatively rapidly. In contrast, the emergence of new ideas took decades longer to impact outcomes. Again, this echoes the observations from both resilience and policy change research that has highlighted the importance of slowly unfolding variables (Walker et al. 2006, Pierson 2004).

Combined, our evidence lends partial support to the second part of $P 1$, which is that the relative influence of different domains changes over time. For most of the time period examined, biophysical drivers did not trigger sustained measurable changes in the variables measured for this system. Past insect outbreaks, droughts, and fires have for the most part been absorbed without long-term impacts on the specific variables measured at the regional scale. This pattern has recently been broken by the mountain pine beetle outbreak (ostensibly the impact of an exogenous ecological driver). Although the future drivers and dynamics of this system remain unclear, given the accelerating impacts of climate and other changes, a proposition for further empirical exploration is that exogenous biophysical drivers may become more dominant in this system in terms of determining outputs and change dynamics.

An alternative or additional interpretation is that some biophysical factors are simply operating at slower rates of change (e.g., climate change, soil degradation), and that these latent variables are imperceptibly active (along with the social), but with consequences yet to be perceived and measured as outputs.

A second issue relating to exogenous as an analytical class concerns interactions between exogenous drivers and endogenous conditions. As influential as exogenous drivers (be they social or ecological) have been in contributing to change at a given point in time in this system, these catalysts are enabled (or constrained) by endogenous social and ecological conditions and historical contingencies. Put differently, although change in policy attributes or outputs may appear sudden and correlated with a given set of forces operating at the time, the roots of change run deep. Consider again, the mountain pine beetle outbreak. This epidemic has occurred on the scale that it has due to a recent spate of successively warmer winters (an exogenous biophysical driver) in combination with decades of forest management that has incentivized planting monoculture pine in combination with manual and chemical brushing programs that have eliminated other non-susceptible plant species (creating vulnerable endogenous conditions).

Another example of the role of endogenous conditions is the decades of latent discontent among various local groups that preceded the widespread international public outcry that erupted to occupy international news headlines in the 1980s and 1990s. Together, these observations fit predictions that endogenous conditions are important mediators of change (Gunderson and Holling 2002) and that change dynamics in complex adaptive ecological and social systems are historically contingent and nonlinear, and have delayed feedbacks.

The points just raised implicate a third issue, which is that what is defined as exogenous or endogenous depends on how one draws the system boundaries. The exercise of parsing exogenous from endogenous, or the relative influence of domains over time, is analytically tractable; however, this approach can only ever yield a partial and contingent explanation of the system.

\section{Transitions to "new" management regimes}

On numerous occasions throughout the 150 years of industrial forest management, "new" policies were proposed, debated, and enacted. In some cases, the benefit of hindsight reveals that new policies represented only incremental changes in practice or changed aspects of governance (e.g., tenure) that did not impact the trajectory of outputs. Sustained yield is an example of such a policy. Other proposals such as those relating to land-use planning in the early 1990s did result in measurable changes in some variables. Whether new policies yielded 
illusory or measurable changes, decision-relevant ecological uncertainties perceived at the time characterized every period of transition. The adoption of sustained yield is a case in point: its implementation depended specifically on technical information known to be unavailable.

This observation supports the proposition that decision-relevant uncertainties are not in and of themselves barriers to the adoption of new policy proposals in particular or adaptation more generally $(P 2)$. It also supports the conclusions made by other scholars that scientific certainty is rarely what is at stake in environmental debates (e.g., Oreskes 2004) even though controversial debates often come to be framed in these terms.

Just as reductions in uncertainty did not spur transitions to new policies, neither did evidence of past policy failure. For instance, over half a century passed between recognition of failed regeneration and the implementation of remedial policies. In this case, the endogenous configuration of entrenched agency, combined with arguments that planting was uneconomical, served as a powerful barrier to change-despite available evidence. This failure to act in the face of evidence is a particularly sobering observation in the context of efforts to develop adaptive policies for resource management given climate change impacts. Not only may we fail to act in the face of evidence, but our ability to perceive many of the impacts of climate change may be delayed in time, thus further complicating the decision-making context.

The above observations contrast with expectations of a linear model of science and society. A linear model holds that science provides objective facts, or "truths" delivered to political actors ("power") to guide policy. In this system, the role of science (here thought of in terms of both uncertainty and evidence) is more accurately described as an indeterminate input given that it has been used both as a barrier and a justification for change. This interpretation fits within the extensive work on the co-production of science and society (e.g., Jasanoff 2004). So, although it may indeed be sobering that decision making does not necessarily act on evidence, the issue of proof and evidence cuts both ways in that policy change relating to ecosystem management can and has occurred amidst great uncertainty.
Given the observations that neither reductions in uncertainties or new evidence are necessarily required to initiate policy change, what factors have been important in this system? What, in addition to awareness and external drivers, is required to initiate measurable policy change? Kingdon (1995) argues that a number of factors increase the chances of a new policy proposal surviving the "selection process:" new proposals need to have gone through a gestation period of "softening up," they must be ready and feasible, and crucially, they must reflect the values of the actors.

The adoption of the PAS proposal in 1993 met all of these criteria. Proposals for protected areas had been part of public and agency discussions for over a decade, an articulated proposal was at the ready (e.g., the WCED), and the proposal itself reflected (and reinforced) assumptions of stable and pristine nature. Finally, all of these factors were in place during the "policy window" that opened with the newly elected provincial government and a swell of changing public values.

\section{Dynamics of Policy Change}

The historical approach taken in this study allows us to examine the proposition that the dynamics of policy change in this system have followed a punctuated equilibrium model (P3). The evidence partially supports this proposition. For the bulk of the time period examined, changes in management regimes were incremental: new names were given to policies whose attributes and outcomes were consistent with previous eras. For example, sustained yield and integrated resource management were governed within a system configuration occupied by the same actors that had the same trajectory of system outputs (e.g., increasing harvesting levels). Over the time period examined, this relative stability was punctuated by a single episode of measurable change characterized by new actors, new institutions, and a new decision-making process, and in some cases, changed outputs (e.g., increased area under protection).

However, although there has been substantive change in some system attributes, ideas of wellbounded, predictable ecosystems have prevailed. Most recently, this is exemplified by biodiversity conservation proposals that seek to predict future patterns of species distributions in order to plan new 
protected areas for the future protection of specific species (Williams et al. 2005). Therefore, we would modify $P 3$ to state that some system attributes have followed a punctuated equilibrium pattern of change, but that whole-scale paradigmatic change has not occurred.

The persistence of ecosystem stability assumptions in practice has important policy implications. As per earlier discussion on ideas, Kingdon (1995) similarly argues that, in order for new proposals to become acceptable, they need to fit the values of key actors. The prevailing command-and-controltype view constrains the decision alternatives at this time and can be seen as a "social basin of attraction" (cf. Walker et al. 2006). Put differently, fidelity to specific ideas can act as a source of positive feedback and as a barrier to change. However, given the increasing complexity and scale of biophysical drivers acting on this system (notably climate change), policies based on predictability and control may eventually become untenable. At that time, policies for dynamic flows of resources (and potentially new forms of management interventions) may become acceptable.

\section{What Lessons Can (and Can't) We Take from History?}

In this analysis, we wanted to know what the historical change dynamics might suggest about potential pathways of future policy iterations. This line of questioning contains both possibilities and constraints. The constraints include the fact that the dynamics of SES are idiosyncratic. A particular disturbance that sets a system down a given path at one period of time is unlikely to be repeated in the future, and if it were, it would be unlikely to yield the same impacts owing to evolving social and ecological configurations. Thus, insights from past dynamics likely tell us more about future potential human behavioral dynamics but not about future potential biophysical changes. On the other hand, the historical evidence suggests patterns beyond idiosyncrasies. In the list below, we return to the propositions posited at the outset of the paper. In doing so, we synthesize some key lessons learned in this system and suggest some generalities that may cautiously be applied to other SES.

Social, exogenous variables have been key contributors of change in this system during the time period examined. There is evidence that this may be changing as slow variables from both biophysical (climate change) and social domains (ideas) may be poised for substantive change $(P l)$.

Prevailing patterns of agency are powerful barriers to change (social basins of attraction) and can result in policies that both maintain and entrench maladaptive policy configurations $(P l)$. When reorganization and change do occur, the features of change are strongly shaped by the current values of key actors in the system. Values change over time.

The reduction of ecological uncertainty (or perceived certainty) is not a requirement for policy change, and crucially, should not be expected as criteria for change. Scientific information and uncertainty are better understood as malleable factors of change and non-change that are mobilized or not depending on other social variables $(P 2)$.

Policy change in this system has unfolded according to a partial pattern of punctuated equilibrium $(P 3)$. Wholesale paradigmatic change across all measured domains was not observed. We wonder if wholesale paradigmatic change across all domains is actually all that common in any SES. For instance, would characterizations of punctuated equilibrium behavior as observed in other systems continue to hold if variables from different domains were examined?

Time is a key variable both in creating a gestation period for new ideas and in allowing for changing values. For example, the command-and-control model of resource management remains entrenched in practice in this system, but perhaps will be challenged in the near future by the potentially transformative impacts of climate change (P3).

\section{CONCLUSIONS}

The analysis above reveals that exogenous factors have been key drivers of change in this system. The impacts of these factors have been mediated by endogenous conditions, which have been shaped by historical contingencies. The analysis further shows that drivers of change originated from a variety of domains (particularly social) and influenced specific (not all) attributes of the SES configuration (i.e., change in SES configuration was partial-not complete). These observations fit a nuanced pattern 
of punctuated equilibrium. However, given the persistence of underlying command-and-control ideas, we would not go so far as to say that paradigmatic change has occurred.

Managed SES are complex adaptive systems in which there is no stable endpoint. This system has co-adapted over time and will continue to do so. Looking ahead in anticipation of future changes, we can cautiously speculate from the insights above that exogenous drivers will be key factors toward change; that biophysical drivers may become more influential than they have been in the recent past; and that innovation will come from outside of the existing configuration of actors. The likelihood of the acceptance of new proposals in future periods of change will be determined by factors including the familiarly of the proposal, its fit with the values of key actors, and its readiness for implementation. It may well be that a previously eschewed proposal will become acceptable as time, ecosystems, and ideas change.

Responses to this article can be read online at:

http://www.ecologyandsociety.org/vol15/iss 1/art2/responses/

\section{Acknowledgments:}

Funding for this work was provided by the National Science Foundation (SES-0345798) through the Climate Decision Making Center (CDMC) at Carnegie Mellon University, and a University Graduate Fellowship from the University of British Columbia. We are further grateful for the detailed and constructive comments of two anonymous reviewers whose suggestions have much improved this paper.

\section{LITERATURE CITED}

Abel, N., D. H. M. Cumming, and J. M.Anderies. 2006. Collapse and reorganization in socialecological systems: questions, some ideas and policy implications. Ecology and Society 11(1): 17. [online] URL: http://www.ecologyandsociety.org/vol11/ iss1/art17/.
Allison, H. E., and R. J. Hobbs. 2004. Resilience, adaptive capacity, and the "lock-in trap" of the western Australian agricultural region. Ecology and Society 9(1): 3. [online] URL: http://www.ecologya ndsociety.org/vol9/iss 1/art3/.

Araújo, M. B., and M. Luoto. 2007. The importance of biotic interactions for modelling species distributions under climate change. Global Ecology and Biogeography 16:743.

Baleshta, K. E., S. W. Simard, R. D. Guy, and C. R. Chanway. 2005. Reducing paper birch density increases Douglas-fir growth rate and Armillaria root disease incidence in southern interior British Columbia. Forest Ecology and Management 208:113.

Baumgartner, F. R., and B. D. Jones. 1991. Agenda dynamics and policy subsystems. Journal of Politics 53:1044-1074.

Berkes, F., and C. Folke. 1998. Linking social and ecological systems: management practices and social mechanisms for building resilience. Cambridge University Press, Cambridge, UK.

Berkes, F., J. Colding, and C. Folke. 2003. Navigating social-ecological systems. Cambridge University Press, Cambridge, UK.

British Columbia Forest Resources Commission. 1991. The future of our forests. Forest Resources Commission, Victoria, British Columbia, Canada.

British Columbia Ministry of Forests and Range (BCMFR). 2008. Mountain pine beetle. BCMFR, Victoria, British Columbia, Canada. [online] http:// www.for.gov.bc.ca/hfp/mountain pine beetle/.

Brownstein, D. 2006. Sunday walks and seed traps: the many natural histories of British Columbia forest conservation, 1890-1925. Dissertation, University of British Columbia, Vancouver, British Columbia, Canada.

Coast Information Team. 2004. Ecosystem-based management plannning handbook. Coast Information Team, Victoria, British Columbia, Canada. [online] URL: http://ilmbwww.gov.bc.ca/citbc/c-ebm-hdbkfin-22mar04.pdf. 
Commission on Resources and the Environment. 1992. Report on a land use strategy for British Columbia. Commission on Resources and the Environment, Victoria, British Columbia, Canada.

Cronon, W. 1996. Uncommon ground: rethinking the human place in nature. W.W. Norton and Company, New York, New York, USA.

Crumley, C. L. 1994. Historical ecology: cultural knowledge and changing landscapes. School of American Research Press, Santa Fe, New Mexico, USA.

Dale, V. H., L. A. Joyce, S. McNulty, R. P. Neilson, M. P. Ayres, M. D. Flannigan, P. J. Hanson, L. C. Irland, A. E. Lugo, C. J. Peterson, D. Simberloff, F. J. Swanson, B. J. Stocks, and M. Wotton. 2001. Climate change and forest disturbances. BioScience 51:723-734.

Daniels, L. D., and R. W. Gray. 2006. Disturbance regimes in coastal British Columbia. BC Journal of Ecosystems and Management 7:44-56.

Demarchi, D. A. 1995. Ecoregions of British Columbia (1:2000 000). British Columbia Ministry of Environment and Parks, Wildlife Branch, Victoria, British Columbia, Canada.

Drushka, K. 1999. In the bight. Harbour Publishing, Madeira Park, British Columbia, Canada.

Gienapp, P., C. Teplitsky, J. S. Alho, J. A. Mills, and J. Merila. 2008. Climate change and evolution: disentangling environmental and genetic responses. Molecular Ecology 17:167-178.

Gillis, R. P., and T. R. Roach. 1986. Lost initiatives: Canada's forest industries, forest policy and forest conservation. Greenwood Press, New York, New York, USA.

Goudie, A. 2000. The human impact on the natural environment. MIT Press, Cambridge, Massachusetts, USA.

Guisan, A., and W. Thuiller. 2005. Predicting species distribution: offering more than simple habitat models. Ecology Letters 8:993-1009.

Gunderson, L. H., and C. S. Holling, editors.
2002. Panarchy: understanding transformations in human and natural systems. Island Press, Washington, D.C., USA.

Gunderson, L. H., C. S. Holling, and S. S. Light. 1995. Barriers and bridges to the renewal of ecosystems and institutions. Columbia University Press, New York, New York, USA.

Hajer, M. A. 1995. The politics of environmental discourse. Ecological modernization and the policy process. Oxford University Press, Oxford, UK and New York, New York, USA.

Hoberg, G. 1996. Putting ideas in their place: a response to "Learning and change in the British Columbia forest policy sector." Canadian Journal of Political Science 29:135.

Holling, C. S. 1973. Resilience and stability of ecological systems. Annual Review of Ecology and Systematics 4:1-23.

Holling C. S., and G. K. Meffe. 1996. Command and control and the pathology of natural resource management. Conservation Biology 10:328-337.

Holling, C. S., L. H. Gunderson, and D. Ludwig. 2002. In quest of a theory of adaptive change. Pages 3-22 in L. H. Gunderson and C. S. Holling, editors. Panarchy: understanding transformations in human and natural systems. Island Press, Washington, D.C., USA.

Howlett, M. 2001. Canadian forest policy. University of Toronto Press, Toronto, Ontario, Canada.

Howlett, M., and M. Ramesh. 2003. Studying public policy: policy cycles and policy subsystems. Oxford University Press, Toronto, Ontario, Canada.

Humphreys, E. R., T. A. Black, K. Morgenstern, Z. Li, and Z. Nesic. 2005. Net ecosystem production of a Douglas-fir stand for 3 years following clearcut harvesting. Global Change Biology 11:450-464.

International Panel on Climate Change (IPCC). 2007. Climate change 2007: synthesis report. Contribution of Working Groups I, II and III to the 
fourth assessment report of the Intergovernmental Panel on Climate Change. IPCC, Geneva, Switzerland.

Jasanoff, S. 2004. States of knowledge: the coproduction of science and social order. Routledge, New York, New York, USA.

Kingdon, J. 1995. Agendas, alternatives and public policies. Harper Collins College Publishers, New York, New York, USA.

Krajina, V. J. 1965. Biogeoclimatic zones and biogeocoenoses of British Columbia. Ecology of Western North America 1:1-17.

Lanskail, D. A. 1985. Resource use conflicts-the forest industry perspective. Pages 45-50 in P. J. Dooling. Parks in British Columbia: emerging results. Parks, Recreation, and Tourism Resources Program, Department of Forest and Resources Management, Faculty of Forestry, University of British Columbia; D. W. Friesen and Sons, Altona, Manitoba, Canada.

Lenoir, J., J. C. Gegout, P. A. Marquet, P. de Ruffray, and H. Brisse. 2008. A significant upward shift in plant species optimum elevation during the 20th century. Science 320:1771.

Lertzman, K., D. Gavin, D. Hallett, L. Brubaker, D. Lepofsky, and R. Mathewes. 2002. Long-term fire regime estimated from soil charcoal in coastal temperate rainforests. Conservation Ecology 6(2): 5. [online] URL: http://www.ecologyandsociety.org/ vol6/iss $2 /$ art5.

Lertzman, K., J. Rayner, and J. Wilson. 1996. Learning and change in the British Columbia forest policy sector: a consideration of Sabatier's advocacy coalition framework. Canadian Journal of Political Science 29:111.

Levin, S. A. 1998. Ecosystems and the biosphere as complex adaptive systems. Ecosystems 1:431-436.

Light, S. S., L. H. Gunderson, and C. S. Holling. 1995. The Everglades: evolution and management in a turbulent ecosystem. Pages 103-168 in L. H. Gunderson, C. S. Holling, and S. S. Light., editors. Barriers and bridges to the renewal of ecosystems and institutions. Columbia University Press, New York, New York, USA.
Lindblom, C. E. 1959. The science of "muddling through." Public Administration Review 19:79-88.

Loo, T. 2006. States of nature: conserving Canada's wildlife in the twentieth century. UBC Press, Vancouver, British Columbia, USA.

Marchak, M. P., S. L. Aycock, and D. M. Herbert. 1999. Falldown: forest policy in British Columbia. David Suzuki Foundation and Ecotrust Canada, Vancouver, British Columbia, Canada.

Marchak, P. 1983. Green gold: the forest industry in British Columbia. UBC Press, Vancouver, British Columbia, Canada.

Meidinger, D., and J. Pojar. 1991. Ecosystems of British Columbia. B.C. Ministry of Forests Research Branch, Victoria, British Columbia, Canada.

Mulholland, F. D. 1937. The forest resources of British Columbia. King's Printer, Victoria, British Columbia, Canada.

Nemani, R. R., C. D. Keeling, H. Hashimoto, W. M. Jolly, S. C. Piper, C. J. Tucker, R. B. Myneni, and S. W. Running. 2003. Climate-driven increases in global terrestrial net primary production from 1982-1999. Science 300:1560-1563.

Niemann,T. 2006. The state of British Columbia's forests. BC Ministry of Forests and Range, Victoria, British Columbia, Canada.

Oreskes, N. 2004. Science and public policy: what's proof got to do with it? Environmental Science and Policy 7:369-383.

Parmesan, C. 2006. Observed ecological and evolutionary impacts of contemporary climate change. Annual Reviews of Ecology and Systematics 37:637-669.

Pearse, P. H. 1976. Timber rights and forest policy in British Columbia. Canada Royal Commission on Forest Resources, Ottawa, Ontario, Canada.

Pearson, R. G., and T.P.Dawson. 2003. Predicting the impacts of climate change on the distribution of species: are bioclimate envelope models useful? Global Ecology and Biogeography 12:361-371.

Pearson, R. G. 2006. Climate change and the 
migration capacity of species. Trends in Ecology and Evolution 21:111-113.

Pielke, R. A. Jr. 2004. When scientists politicize science: making sense of controversy over The Skeptical Environmentalist. Environmental Science and Policy 7:405-417.

Pierson, P. 2004. Politics in time: history, institutions and social analysis. Princeton University Press, Princeton, New Jersey, USA.

Pojar, J., K. Klinka, and D. Meidinger. 1987. Biogeoclimatic ecosystem classification in British Columbia. Forest Ecology and Management 22:119-154.

Province of British Columbia. 1911. Statutes of the province of British Columbia: an act respecting Strathcona Park. King's Printer, Victoria, British Columbia, Canada.

Province of British Columbia. 1993. A protected areas strategy for British Columbia. Queen's Printer, Victoria, British Columbia, Canada.

Province of British Columbia, Department of Lands. 1913. Report of the Forest Branch. King's Printer, Victoria, British Columbia, Canada.

Province of British Columbia, Department of Lands. 1914. Report of the Forest Branch. King's Printer, Victoria, British Columbia, Canada.

Province of British Columbia, Department of Lands. 1921. Report of the Forest Branch. King's Printer, Victoria, British Columbia, Canada.

Province of British Columbia, Department of Lands. 1926. Report of the Forest Branch. King's Printer, Victoria, British Columbia, Canada.

Province of British Columbia, Department of Lands. 1936. Report of the Forest Branch. King's Printer, Victoria, British Columbia, Canada.

Province of British Columbia, Department of Lands. 1938. Report of the Forest Branch. King's Printer, Victoria, British Columbia, Canada.

Province of British Columbia, Department of Lands. 1939. Report of the Forest Branch. King's Printer, Victoria, British Columbia, Canada.
Province of British Columbia, Department of Lands, Forests and Water Resources. 1969 Report of the Forest Service. Queen's Printer, Victoria, British Columbia, Canada.

Province of British Columbia, Department of Lands, Forests and Water Resources. 1971. Report of the Forest Service. Queen's Printer, Victoria, British Columbia, Canada.

Province of British Columbia, Department of Lands, Forests and Water Resources. 1972. Report of the Forest Service. Queen's Printer, Victoria, British Columbia, Canada.

Province of British Columbia, Department of Lands, Forests and Water Resources. 1974. Report of the Forest Service. Queen's Printer, Victoria, British Columbia, Canada.

Province of British Columbia, Department of Recreation and Conservation. 1957. Report of the Department of Recreation and Conservation. Queen's Printer, Victoria, British Columbia, Canada.

Province of British Columbia, Department of Recreation and Conservation. 1964. Report of the Department of Recreation and Conservation. Queen's Printer, Victoria, British Columbia, Canada.

Province of British Columbia, Ministry of Forests and Lands. 1987. Annual report of the Ministry of Forests and Lands. Queen's Printer, Victoria, British Columbia, Canada.

Province of British Columbia, Ministry of Parks. 1988. Annual Report of the Ministry of Parks. Queen's Printer, Victoria, British Columbia, Canada.

Rajala, R. A. 1998. Clearcutting the Pacific rain forest: production science and regulation. UBC Press, Vancouver, British Columbia, Canada.

Rajala, R. A. 2006. Up-coast: forests and industry on British Columbia's North Coast, 1870-2005. Royal British Columbia Museum, Victoria, British Columbia, Canada.

Repetto, R. 2006. Punctuated equilibrium and the dynamics of U.S. environmental policy. Yale University Press, New Haven, Connecticut, USA. 
Reynolds, J. F., M. D. Stafford Smith, E. F. Lambin, B. L. Turner, II, M. Mortimore, S. Batterbury, T. E. Downing, H. Dowlatabadi, R. Fernandez, J. E. Herrick, E. Huber-Sannwald, H. Jiang, R. Leemans, T. Lynam, F. T. Maestre, M. Ayarza, and B. Walker, B. 2007. Global desertification: building a science for dryland development. Science 316:847-851.

Rinnan, R. A., A. Michelsen, E. Bååth, and S. Jonasson. 2007. Fifteen years of climate change manipulations alter soil microbial communities in a subarctic heath ecosystem. Global Change Biology 13:28-39.

Root, T. L., J. T. Price, K. R. Hall, S. H. Schneider, C. Rosenzweig, and J. A. Pounds. 2003. Fingerprints of global warming on wild animals and plants. Nature 421:57-60.

Rotmans, J., and M. van Asselt. 2000. Integrated assessment modelling. Pages 239-275 in P. Martens and J. Rotmans, editors. Climate change: an integrated perspective. Kluwer Academic Publishers, New York, New York, USA.

Sabatier, P. A., editor. 2007. Theories of the policy process. Westview Press, Boulder, Colorado, USA.

Sabatier, P. A., and Jenkins-Smith, editors. 1993. Policy change and learning: an advocacy coalition approach. Westview Press, Boulder, Colorado, USA.

Safranyik, L., and A. L. Carroll. 2006. The biology and epidemiology of the mountain pine beetle in lodgepole pine forests. Pages 3-66 in L. Safranyik and B. Wilson, editors. The mountain pine beetle: a synthesis of its biology and management in lodgepole pine. Natural Resources Canada, Canadian Forest Service - Pacific Forestry Centre, Victoria, British Columbia, Canada.

Safranyik, L., D. M. Shrimpton, and H. S. Whitney. 1974. Management of lodgepole pine to reduce losses from the mountain pine beetle. Natural Resources Canada, Canadian Forest Service Pacific Forestry Centre, Victoria, British Columbia, Canada.
Simard, S. W., D.A. Perry, M. D. Jones, D. Durall, and R. Molina. 1997. Net transfer of carbon between ectomycorrhizal tree species in the field. Nature 388:579-582.

Sloan, G. M. 1945. Report of the Commissioner, the Honourable Gordon McG. Sloan, Chief Justice of British Columbia relating to the forest resources of British Columbia. King's Printer, Victoria, British Columbia, Canada.

Sloan, G. M. 1957. Report of the Commissioner Honourable Gordon McG. Sloan, Chief Justice of British Columbia relating to the forest resources of British Columbia. Queen's Printer, Victoria, British Columbia, Canada.

Taylor, S. W., and A. L. Carroll. 2004. Disturbance, forest age, and mountain pine beetle dynamics in B.C.: a historical perspective. Mountain pine beetle symposium: challenges and solutions. Natural Resources Canada, Canadian Forest Service - Pacific Forestry Centre, Victoria, British Columbia, Canada.

Turner, B. L., W. C. Clark, R. W. Kates, J. F. Richards, J. T. Matthews, and W. B. Meyer. 1990. The earth as transformed by human action: global and regional changes in the biosphere over the past 300 years. Cambridge University Press with Clark University, Cambridge, UK.

United Nations. 1993. Text of the Convention on Biological Diversity. Concluded at Rio de Janeiro on 5 June 1992. Pages 142-382 in Volume 1760. United Nations Treaty Series. United Nations, New York, New York, USA.

Walker, B., L. Gunderson, A. Kinzig, C. Folke, S. Carpenter, and L. Schultz. 2006. A handful of heuristics and some propositions for understanding resilience in social-ecological systems. Ecology and Society 11(1): 13. [online] URL: http://www.ec ologyandsociety.org/vol11/iss1/art13/.

Walker, B., C. S. Holling, S. R. Carpenter, and A. Kinzig. 2004. Resilience, adaptability and transformability in social-ecological systems. Ecology and Society 9(2): 5. [online] URL: http://w ww.ecologyandsociety.org/vol9/iss2/art5/.

Whitford, H. N., and R. D. Craig. 1918. Forests 
of British Columbia. Commission of Conservation Canada, Ottawa, Ontario, Canada.

Williams, P., L. Hannah, S. Andelman, G. Midgley, M. Araújo, G. Hughes, L. Manne, E. Martinez-Meyer, and R. Pearson. 2005. Planning for climate change: identifying minimum-dispersal corridors for the Cape Proteaceae. Conservation Biology 19:1063-1074.

Wilson, J. 1998. Talk and log: wilderness politics in British Columbia, 1965-1996. UBC Press, Vancouver, British Columbia, Canada.

Wong, C., H. Sandmann, and B. Dorner. 2004. Historical variability of natural disturbances in British Columbia: a literature review. FORREXForest Research Extension Partnership, Kamloops, British Columbia, Canada.

Woodward, F. I., and D. J. Beerling. 1997. The dynamics of vegetation change: health warnings for equilibrium "dodo" models. Global Ecology and Biogeography 6:413-418.

World Commission on Environment and Development. 1987. Our common future. Oxford University Press, Oxford, UK.

Wynn, G. 2004. "Shall we linger along ambitionless?": environmental perspectives on British Columbia. BC Studies 142/143:5-67. 